\title{
Elasticity of substitution and productivity, capital and skill intensity differences across firms
}

Citation for published version (APA):

Dupuy, A., \& de Grip, A. (2006). Elasticity of substitution and productivity, capital and skill intensity differences across firms. Economics Letters, 90(3), 340-347. https://doi.org/10.1016/j.econlet.2005.08.025

Document status and date:

Published: 01/01/2006

DOI:

10.1016/j.econlet.2005.08.025

Document Version:

Publisher's PDF, also known as Version of record

\section{Please check the document version of this publication:}

- A submitted manuscript is the version of the article upon submission and before peer-review. There can be important differences between the submitted version and the official published version of record. People interested in the research are advised to contact the author for the final version of the publication, or visit the DOI to the publisher's website.

- The final author version and the galley proof are versions of the publication after peer review.

- The final published version features the final layout of the paper including the volume, issue and page numbers.

Link to publication

\footnotetext{
General rights rights.

- You may freely distribute the URL identifying the publication in the public portal. please follow below link for the End User Agreement:

www.umlib.nl/taverne-license

Take down policy

If you believe that this document breaches copyright please contact us at:

repository@maastrichtuniversity.nl

providing details and we will investigate your claim.
}

Copyright and moral rights for the publications made accessible in the public portal are retained by the authors and/or other copyright owners and it is a condition of accessing publications that users recognise and abide by the legal requirements associated with these

- Users may download and print one copy of any publication from the public portal for the purpose of private study or research.

- You may not further distribute the material or use it for any profit-making activity or commercial gain

If the publication is distributed under the terms of Article $25 \mathrm{fa}$ of the Dutch Copyright Act, indicated by the "Taverne" license above, 


\title{
Elasticity of substitution and productivity, capital and skill intensity differences across firms
}

\author{
Arnaud Dupuy *, Andries de Grip \\ Research Center for Education and the Labour Market (ROA), Maastricht University PO Box 616, \\ NL-6200 MD, The Netherlands
}

Received 12 January 2005; received in revised form 28 June 2005; accepted 30 August 2005

Available online 27 December 2005

\begin{abstract}
This paper, instrumented with six theorems, shows that differences between firms in labor productivity, capital intensity and relative demand for skilled labor can be explained by differences in the substitution parameters between capital, skilled and unskilled labor in the presence of skill biased technical change.
\end{abstract}

(C) 2005 Elsevier B.V. All rights reserved.

Keywords: Elasticity of substitution; Labor productivity; Capital intensity and skill biased technical change

JEL classification: D24; D21; J21; L11

\section{Introduction}

Empirical analyses reveal tremendous heterogeneity in output, labor productivity and input mix across firms (see Abowd et al., 1999 for instance) even in narrowly defined industries (Baily et al., 1992 and Olley and Pakes, 1996). This paper gives a theoretical explanation of the differences in labor productivity, capital intensity and relative demand for skilled labor between firms. Our study builds on Klump and de La Grandville (2000), who proved that a higher elasticity of substitution between labor and capital will result in a higher level of labor productivity in the steady-state. The magnitude of the elasticity of substitution actually determines the range of possibilities available to employers. The higher

\footnotetext{
* Corresponding author. Tel.: +31 433883 647; fax: +31 433884914.

E-mail address: a.dupuy@roa.unimaas.nl (A. Dupuy).
} 
this elasticity, the greater the possibilities offered to employers for producing a given level of output with different factor combinations. Generalizing Klump and de La Grandville's (2000) theorems to the twolevel constant elasticity of substitution (CES) function, Papageorgiou and Saam (2005) proved that at given input values, the larger the substitution parameter between skilled labor and capital or between skilled and unskilled labor, the larger labor productivity. We contribute to this literature and prove two new theorems regarding the effect of substitution parameters on the demand for skilled and unskilled labor in the presence of skill biased technical change. We prove that i) holding skilled labor and the rate of skilled labor augmenting technical change constant, the larger the substitution parameter between skilled labor and capital the larger the rate of change in the relative demand for skilled labor and ii) holding skilled labor and the rates of skilled labor augmenting and unskilled labor saving technical change constant, the larger the substitution parameter between unskilled and skilled labor the larger the decrease in the demand for unskilled labor. These two theorems contribute to the large literature on skill biased technical change using nested CES. They prove that in addition to being affected by changes in the factor augmenting parameters, the demand for skilled and unskilled labor is also sensitive to changes in the substitution parameters.

The structure of the paper is as follows. In Section 2, we first discuss two theorems of Klump and de La Grandville (2000) on the relationship between the substitution parameter between labor and capital and labor productivity and capital intensity of firms and their generalization to nested CES by Papageorgiou and Saam (2005). Thereafter, we discuss our two theorems on the relationship between the ease to substitute between skilled and unskilled labor and capital and a firm's labor productivity and skill intensity. In Section 3 we discuss the implications of our theorems.

\section{Elasticities of substitution, labor productivity, skill intensity and capital intensity}

de La Grandville (1989) shows an important property of the elasticity of substitution: the increase in the production due to a decrease in one factor price is an increasing function of the elasticity of substitution between the factors of production. Using a family of CES isoquants he shows that the change in the maximum production level at a given total cost if the price of one input decreases is larger the larger the elasticity of substitution between inputs.

Klump and de La Grandville (2000) use this result to derive two theorems linking the elasticity of substitution between capital and labor with labor productivity and capital intensity.

Let us consider a firm, who maximizes profits and produces output, $H$, by combining capital and labor inputs, say $K$ and $L$.

The production function of the firm takes the form of a homogenous of degree one normalized-CES production function $^{1}$ so that labor productivity reads as follows:

$$
\frac{H_{\sigma}(K, L) z}{L}=h_{\sigma}(k)=h_{0}\left(\delta+(1-\delta) \times\left(\frac{k}{k_{0}}\right)^{(\sigma-1) / \sigma}\right)^{\sigma /(\sigma-1)}
$$

\footnotetext{
${ }^{1}$ We are interested in comparing production functions which differ from one another by their substitution parameter only. Therefore we normalize the various production functions at some arbitrarily chosen baseline values of the three variables that define the elasticity of substitution: capital intensity at $t=0$ is equal to $k_{0}=\frac{K_{0}}{L_{0}}$, the marginal rate of substitution between capital and labor at $t=0$ is $\frac{\partial H / \partial L}{\partial H / \partial K}\left(K_{0}, L_{0}\right)=\frac{\delta}{1-\delta}\left(=\mu_{0}\right.$ in Klump and Preissler (2000)) and labor productivity is $H_{0} / L_{0}$. See Klump and Preissler (2000) for a presentation of the family of normalized CES production functions.
} 
where $k=K / L$ is the capital intensity, $k_{0}=\frac{K_{0}}{L_{0}}$ and $L_{0}$ and $K_{0}$ are the initial employment and capital stock and $h_{0}=\frac{H_{0}}{L_{0}}$ and $H_{0}$ is the initial output level, $\delta$ is a technology parameter and $\sigma$ is the substitution parameter between capital and labor. Note that $\frac{\partial H / \partial L}{\partial H / \partial K}\left(K_{0}, L_{0}\right)=\frac{\delta}{1-\delta}$ independent of $\sigma$.

Klump and de La Grandville (2000) prove that $\frac{\partial h_{\sigma}(k)}{\partial \sigma} 0$ for all $k$. From this result they derive their two theorems on the relationship between the substitution parameter and the capital intensity and labor productivity. $^{2}$

Theorem 1. If two firms are described by CES production functions differing only by their substitution parameter and share initially a common capital-labor ratio $\bar{k}$, the same employment growth $\dot{L}$, and investment rate $s$, then at any stage of its development the firm with the largest substitution parameter will have a higher level of labor productivity. (cf. Klump and de La Grandville (2000) p.285).

Theorem 2. If two firms are described by CES production functions differing only by their substitution parameter and share initially a common capital-labor ratio $\bar{k}$, the same employment growth $\dot{L}$, and investment rate $s$, and if the levels of the substitution parameter guarantee the existence of steady states, then the firm with the largest substitution parameter between capital and labor will have a higher capital intensity and higher labor productivity in the steady state. (cf. Klump and de La Grandville (2000) p. 286).

Consider now a firm that maximizes profits and produces output, $H$, by combining capital $K$ with unskilled and skilled labor, say $L_{\mathrm{u}}$ and $L_{\mathrm{s}}$. The production function of the firm takes the form of a homogenous of degree one normalized ${ }^{3}$ 2-level CES production function. As Krusell et al. (2000), we assume that capital and skilled labor are complementary in production and consider the following nests:

$$
\begin{aligned}
\frac{H\left(L_{\mathrm{u}}, L_{\mathrm{s}}, K\right)}{L_{s}+L_{u}} & =h_{\sigma_{\mathrm{s}}, \sigma_{\mathrm{u}}}\left(p, g_{\sigma_{\mathrm{s}}}\left(\frac{k}{p}\right)\right) \\
& =h_{0}\left(\lambda \times\left(\frac{1-p}{1-p_{0}}\right)^{\left(\sigma_{\mathrm{u}}-1\right) / \sigma_{\mathrm{u}}}+(1-\lambda) \times\left(\frac{p g_{\sigma_{\mathrm{s}}}\left(\frac{k}{p}\right)}{p_{0} g_{\sigma_{\mathrm{s}}}\left(\frac{k_{0}}{p_{0}}\right)}\right)^{\left(\sigma_{\mathrm{u}}-1\right) / \sigma_{\mathrm{u}}}\right)^{\sigma_{\mathrm{u}} /\left(\sigma_{\mathrm{u}}-1\right)}
\end{aligned}
$$

with

$$
g_{\sigma_{\mathrm{s}}}\left(\frac{k}{p}\right)=\left(\delta+(1-\delta) \times\left(\frac{k}{p} \frac{p_{0}}{k_{0}}\right)^{\left(\sigma_{\mathrm{s}}-1\right) / \sigma_{\mathrm{s}}}\right)^{\sigma_{\mathrm{s}} /\left(\sigma_{\mathrm{s}}-1\right)}
$$

where $L=L_{\mathrm{s}}+L_{\mathrm{u}}$ is total employment, $p=\frac{L_{\mathrm{s}}}{L}$ is the share of skilled labor in total employment and $p_{0}$ the initial share of skilled workers and $k=\frac{K}{L}$ is the capital intensity, $\lambda$ and $\delta$ are technology parameters and $\sigma_{\mathrm{s}}$ is the substitution parameter between capital and skilled labor, and $\sigma_{\mathrm{u}}$ is the substitution parameter

\footnotetext{
2 The steady-state theorems of Klump and de La Grandville do not apply to production functions in which skilled and unskilled labor are differentiated. For the heterogeneous labor case, the positive effect of an increase in either of the two substitution parameters on the steady-state capital intensity is proved in Papageorgiou and Saam (2005).

3 The normalization in the three-input case consists of a baseline for the capital intensity $k_{0}$, the skill intensity $p_{0}$, labor productivity $h_{0}$ and the marginal rate of substitution between skilled labor and capital (lower nest) $\frac{\partial g \partial p}{\partial g \partial k}=\zeta_{0}=\frac{\delta}{1-\delta}$ and the marginal rate of substitution between unskilled labor and the input mix of skilled labor and capital $\frac{\partial h \partial L_{u}}{\partial h \partial g}=\tau_{0}=\frac{\lambda}{1-\lambda}$.
} 
between skilled and unskilled labor and between capital and unskilled labor. Note that capital-skill complementarity holds if $\sigma_{\mathrm{u}}>\sigma_{\mathrm{s}}$.

A generalization of Klump and de La Grandville's (2000) Theorem 1 to the two-level CES production function is given in Theorems 3 and 4. The proof of Theorem 3 follows quite easily from Klump and de La Grandville's Theorem 1, once recognized that $g_{\sigma_{s}}\left(\frac{k}{p}\right)$ is identical to the $h_{\sigma}(k)$ function used by Klump and de La Grandville (2000). ${ }^{4}$ Theorem 4 has recently been proved by Papageorgiou and Saam (2005).

Theorem 3. If two firms are described by 2-level CES production functions á la Krusell et al. (2000), differing only by their substitution parameter between skilled labor and capital $\sigma_{\mathrm{s}}$, at equivalent labor force composition $p$ and capital intensity $k$, any $p$ and $k$, the firm with the largest substitution parameter will have the highest labor productivity.

Theorem 4. If two firms are described by 2-level CES production functions á la Krusell et al. (2000), differing only by their substitution parameter between skilled and unskilled labor $\sigma_{\mathrm{u}}$ at equivalent labor force composition $p$ and capital intensity $k$, any $p$ and $k$, the firm with the largest substitution parameter will have the highest labor productivity. (cf. Papageorgiou and Saam (2005) p.5).

To these four theorems we add two new theorems on the effect of the substitution parameters on the demand for skilled and unskilled labor in the presence of skill biased technological change. ${ }^{5}$

Theorem 5. If two firms are described by 2-level CES production functions á la Krusell et al. (2000), differing only by their substitution parameter between skilled and capital $\sigma_{s}$ and their substitution parameter between skilled and unskilled labor $\sigma_{u}$ and share initially a common skill intensity, i.e. $L_{\mathrm{s}} / L_{\mathrm{u}}$ and a skilled labor augmenting technological change characterized by the same function $m_{s}$ ( $t$ ) (same rate of skilled labor augmenting $L_{s}$, i.e. $\left.m_{s}^{\prime}\right)$, then, the firm with the largest substitution parameter between skilled labor and capital will have a larger rate of change in the relative demand for skilled workers.

Proof. To prove Theorem 5, consider the 2-level CES production function with non-neutral, $L_{\mathrm{u}}$ saving and $L_{\mathrm{s}}$ augmenting technological change.

$$
H_{\sigma_{\mathrm{u}}, \sigma_{\mathrm{s}}}\left(L_{\mathrm{u} t}, L_{\mathrm{s} t}, K_{t}\right)=\left(\lambda \times\left(m_{\mathrm{u}}(t) \frac{L_{\mathrm{u} t}}{L_{\mathrm{u} 0}}\right)^{\left(\sigma_{\mathrm{u}}-1\right) / \sigma_{\mathrm{u}}}+(1-\lambda) \times\left(\frac{G_{\sigma_{\mathrm{s}}}\left(L_{\mathrm{s} t}, K_{t}\right)}{G_{\sigma_{\mathrm{s}}}\left(L_{\mathrm{s} 0}, K_{0}\right)}\right)^{\left(\sigma_{\mathrm{u}}-1\right) / \sigma_{\mathrm{u}}}\right)^{\sigma_{\mathrm{u}} /\left(\sigma_{\mathrm{u}}-1\right)}
$$

with

$$
G_{\sigma_{\mathrm{s}}}\left(L_{\mathrm{s} t}, K_{t}\right)=\left(\delta\left(m_{\mathrm{s}}(t) \frac{L_{\mathrm{s} t}}{L_{\mathrm{s} 0}}\right)^{\left(\sigma_{\mathrm{s}}-1\right) / \sigma_{\mathrm{s}}}+(1-\delta) \times\left(\frac{K_{t}}{K_{0}}\right)^{\left(\sigma_{\mathrm{s}}-1\right) / \sigma_{\mathrm{s}}}\right)^{\sigma_{\mathrm{s}} /\left(\sigma_{\mathrm{s}}-1\right)}
$$

where $m_{u}^{\prime}=\left(1 / m_{u}\right)\left(\mathrm{d} m_{u} / \mathrm{d} t\right)$ is the rate of unskilled labor saving technological change at time $t$ and $m_{\mathrm{u}}>0$ and $m_{\mathrm{u}}^{\prime} \leq 0$ and $m_{\mathrm{s}}^{\prime}=\left(1 / m_{\mathrm{s}}\right)\left(\mathrm{d} m_{\mathrm{s}} / \mathrm{d} t\right)$ is the rate of skilled labor augmenting technological change at time $t$ and $m_{\mathrm{s}}>0$ and $m_{\mathrm{s}}^{\prime}>0$.

\footnotetext{
4 See Papageorgiou and Saam (2005).

5 For an exhaustive survey of the large literature on skill biased technical change see Katz and Autor (2000) and Autor et al. (2003).
} 
Deriving Eq. (4) with respect to each input factor yields the marginal productivity of $L_{\mathrm{u}}$ and $L_{\mathrm{s}}$ and $K$ :

$$
\begin{aligned}
& \partial H_{\sigma_{\mathrm{u}}, \sigma_{\mathrm{s}}} / \partial L_{\mathrm{u} t}=\lambda\left(\frac{H_{t}}{L_{\mathrm{u} t}}\right)^{1 / \sigma_{\mathrm{u}}} L_{\mathrm{u} 0}^{\frac{1-\sigma_{\mathrm{u}}}{\sigma_{\mathrm{u}}}} m_{\mathrm{u}}^{\left(\sigma_{\mathrm{u}}-1\right) / \sigma_{\mathrm{u}}}(t)=w_{\mathrm{u} t} \\
& \partial H_{\sigma_{\mathrm{u}}, \sigma_{\mathrm{s}}} / \partial L_{\mathrm{s} t}=(1-\lambda)\left(\frac{\partial G_{\sigma_{\mathrm{s}}}}{\partial L_{\mathrm{s} t}}\right)\left(\frac{H_{t}}{G_{\sigma_{\mathrm{s}}}}\right)^{1 / \sigma_{\mathrm{u}}}=w_{\mathrm{s} t} \\
& \partial H_{\sigma_{\mathrm{u}}, \sigma_{\mathrm{s}}} / \partial K_{t}=(1-\lambda)\left(\frac{\partial G_{\sigma_{\mathrm{s}}}}{\partial K_{t}}\right)\left(\frac{H_{t}}{G_{\sigma_{\mathrm{s}}}}\right)^{1 / \sigma_{\mathrm{u}}}=r_{t}
\end{aligned}
$$

where

$$
\begin{aligned}
\frac{\partial G_{\sigma_{\mathrm{s}}}}{\partial K_{t}} & =(1-\delta)\left(\frac{G_{\sigma_{s}}\left(L_{\mathrm{s} t}, K_{t}\right)}{K_{t}}\right)^{1 / \sigma_{\mathrm{s}}} K_{0}^{\frac{1-\sigma_{\mathrm{s}}}{\sigma_{\mathrm{s}}}} \\
\frac{\partial G_{\sigma_{\mathrm{s}}}}{\partial L_{\mathrm{s} t}} & =\delta\left(\frac{G_{\sigma_{\mathrm{s}}}\left(L_{\mathrm{s} t}, K_{t}\right)}{L_{\mathrm{s} t}}\right)^{1 / \sigma_{\mathrm{s}}} L_{\mathrm{s} 0}^{\frac{1-\sigma_{\mathrm{s}}}{\sigma_{\mathrm{s}}}} m_{\mathrm{s}}^{\left(\sigma_{s}-1\right) / \sigma_{\mathrm{s}}}(t)
\end{aligned}
$$

and $w_{\mathrm{u} t}$ and $w_{\mathrm{s} t}$ are the wage rates of unskilled and skilled workers, respectively, and $r_{t}$ is the price of capital.

Dividing Eq. (7) by Eq. (8), taking the logarithm form and rearranging, the demand for skilled labor reads as:

$$
\ln L_{\mathrm{s} t}=\sigma_{\mathrm{s}} \ln \frac{\delta}{1-\delta}-\sigma_{\mathrm{s}} \ln \frac{w_{\mathrm{s} t}}{r_{t}}+\left(\sigma_{\mathrm{s}}-1\right)\left(\ln m_{\mathrm{s}}(t)+\ln \frac{K_{0}}{L_{\mathrm{s} 0}}\right)+\ln K_{t} .
$$

The change in the demand for skilled workers at constant input prices and capital stock reads as:

$$
\mathrm{d} \ln L_{\mathrm{s} t}=\left(\sigma_{s}-1\right) \mathrm{d} \ln m_{\mathrm{s}}(t) .
$$

Deriving Eq. (12) with respect to $\sigma_{\mathrm{s}}$ at constant prices and stock of capital yields:

$$
\frac{\partial\left(\mathrm{d} \ln L_{\mathrm{s} t}\right)}{\partial \sigma_{s}}=\mathrm{d} \ln m_{\mathrm{s}}(t)>0 .
$$

Hence, the larger the substitution parameter between skilled workers and capital, the larger the rate of increase of the demand for skilled workers associated to skilled labor augmenting technological change.

Theorem 6. If two firms are described by 2-level CES production functions á la Krusell et al. (2000), differing only by their elasticity of substitution parameter between skilled labor and capital $\sigma_{s}$ and their elasticity of substitution parameter between skilled and unskilled labor $\sigma_{u}$, and initially share a common skill intensity, i.e. $L_{s} / L_{u}$ and an unskilled labor saving technological change characterized by the same function $m_{u}(t)$ (same rate of unskilled labor saving $L_{u}$, i.e. $m_{u}^{\prime}$ ) and a skilled labor augmenting technological change characterized by the same function $m_{s}(t)$ (same rate of skilled labor augmenting $L_{s}$, i.e. $\left.m_{s}^{\prime}\right)$, then, the firm with the largest elasticity of substitution parameter between skilled and capital will have a larger rate of change in the relative demand for unskilled and skilled workers. 
Proof. To prove Theorem 6 note that, from Eqs. (6) and (8), we can derive the log demand for unskilled labor relative to the stock of capital as follows:

$$
\begin{aligned}
\ln L_{\mathrm{u} t}= & \sigma_{\mathrm{u}} \ln \frac{\lambda}{1-\lambda}-\sigma_{\mathrm{u}} \ln (1-\delta)-\sigma_{\mathrm{u}} \ln \frac{w_{\mathrm{u} t}}{r_{t}}+\left(\sigma_{\mathrm{u}}-1\right)\left(\ln m_{\mathrm{u}}(t)-\ln L_{\mathrm{u} 0}\right) \\
& +\left(1-\frac{\sigma_{\mathrm{u}}}{\sigma_{\mathrm{s}}}\right) \ln G_{\sigma_{\mathrm{s}}}+\frac{\sigma_{\mathrm{u}}}{\sigma_{\mathrm{s}}} \ln K_{t}+\left(\sigma_{\mathrm{s}}-1\right) \frac{\sigma_{\mathrm{u}}}{\sigma_{\mathrm{s}}} \ln K_{0} \\
\text { where } G_{\sigma_{\mathrm{s}}}= & \left(\delta\left(m_{\mathrm{s}}(t) \frac{L_{\mathrm{st}}}{L_{\mathrm{s} 0}}\right)^{\left(\sigma_{\mathrm{s}}-1\right) / \sigma_{\mathrm{s}}}+(1-\delta) \times\left(\frac{K_{t}}{K_{0}}\right)^{\left(\sigma_{\mathrm{s}}-1\right) / \sigma_{\mathrm{s}}}\right)^{\sigma_{\mathrm{s}} /\left(\sigma_{\mathrm{s}}-1\right)} .
\end{aligned}
$$

At constant prices and capital stock, the change in the demand for unskilled labor reads as:

$$
\mathrm{d} \ln L_{\mathrm{u} t}=\left(\sigma_{\mathrm{u}}-1\right) \ln m_{\mathrm{u}}(t)+\left(1-\frac{\sigma_{\mathrm{u}}}{\sigma_{\mathrm{s}}}\right) \mathrm{d} \ln G \sigma_{\mathrm{s}} .
$$

Deriving Eq. (15) with respect to $\sigma_{\mathrm{u}}$ at constant prices and stock of capital yields:

$$
\frac{\partial\left(\mathrm{d} \ln L_{\mathrm{u} t}\right)}{\partial \sigma_{\mathrm{u}}}=\mathrm{d} \ln m_{\mathrm{u}}(t)-\frac{1}{\sigma_{\mathrm{s}}} \mathrm{d} \ln G_{\sigma_{\mathrm{s}}} .
$$

Note that at constant input prices and capital stock, the aggregate input $G_{\sigma \mathrm{s}}$ increases with time if $m_{\mathrm{s}}^{\prime}>0$ and remains constant when $m_{\mathrm{s}}^{\prime}=0$. Hence, $\frac{\partial\left(\mathrm{d} \ln L_{\mathrm{ut}}\right)}{\partial \sigma_{\mathrm{u}}}>0$ since $\operatorname{dln} m_{\mathrm{u}}(t)<0$ and $\frac{1}{\sigma_{\mathrm{s}}} \mathrm{d} \ln G_{\sigma_{\mathrm{s}} \geq 0}$. The larger the substitution parameter between skilled and unskilled labor the larger the decrease in the demand for unskilled labor associated to unskilled labor saving technological change.

\section{Conclusion}

The theoretical results presented in this paper have two important empirical applications. First, they offer a new explanation for the differences in productivity, capital intensity and the relative demand for skilled labor across firms (see Abowd et al., 1999 for instance) even in narrowly defined industries (Baily et al., 1992 and Olley and Pakes, 1996), and especially across firm-size. Inter firm-size differences in the substitution parameters between skilled and unskilled labor and capital can explain empirical evidence that large firms have a significantly higher labor productivity (see Idson and Oi., 1999 and Haltiwanger et al., 1999 for instance), a larger capital to labor ratio (see Oi, 1983) and a workforce with a higher educational attainment (see Oi, 1983 and Haltiwanger et al., 1999) than small firms. An intuitive explanation of differences in the ease to substitute labor inputs across firms leans towards factors like how work is organized at the work floor and how workers are supervised since these variables systematically vary between firms and industries. Although there is a growing literature on the impact of advanced human resources practices on productivity (see Black and Lynch, 2001 and Ichniowski and Shaw, 2003), none of these studies analyzed the impact of these practices on the substitution parameters. ${ }^{6}$ Further research should test for significant differences in the elasticity of substitution between the various inputs across firms especially with respect to firm size.

\footnotetext{
${ }^{6}$ Black and Lynch (2001) use a Cobb-Douglas production function where the ease to substitute between production and nonproduction workers is equal to unit for all firms regardless of their Human Resources Management (HRM) system.
} 
Moreover, the two new theorems presented in this paper offer a new explanation for differences in the patterns of skill premia observed across countries (see for instance Blau and Kahn, 1996 and Acemoglu, 2003) and in different time periods (see Autor et al., 1998 and Acemoglu, 2002), namely cross-country differences and changes through time in the substitution parameter between skilled and unskilled labor. $^{7}$

\section{Acknowledgements}

We thank participants at the European Association of Labour Economists meeting in Paris 2002, ROA and CLS seminars; Lex Borghans, Bart Golsteyn, Philip Marey, Inge Sieben, Wendy Smits and an anonymous referee for helpful comments. Arnaud Dupuy thanks the Marie Curie funding for financial support.

\section{References}

Abowd, J., Kramarz, F., Margolis, D., 1999. High wage workers and high wage firms. Econometrica 67 (2), $251-333$. Acemoglu, D., 2002. Technical change, inequality and the labor market. Journal of Economic Literature 40 (1), 7-72. Acemoglu, D., 2003. Cross-country inequality trends. Economic Journal 113, 121-149.

Autor, D., Katz, L., Krueger, A., 1998. Computing inequality: have computers changed the labor market? Quarterly Journal of Economics 113 (4), 1169-1213.

Autor, D., Levy, F., Murnane, R., 2003. The skill content of recent technological change: an empirical exploration. Quarterly Journal of Economics 118 (4).

Baily, M., Hulten, C., Campbell, D., 1992. Productivity dynamics in manufacturing plants. Brookings Papers on Economic Activity, Microeconomics, pp. 187-249.

Black, S., Lynch, L., 2001. How to compete: the impact of workplace practices and information technology on productivity. Review of Economics and Statistics 83 (3), 434-445.

Blau, F., Kahn, L., 1996. International differences in male wage inequality: institutions versus market forces. Journal of Political Economy 104 (4), $791-837$.

de La Grandville, O., 1989. In quest of the slutsky diamond. American Economic Review 79 (3), 468 -481.

Dupuy, A., Marey, P., 2004. Shifts and twists in the relative productivity of skilled labor: reconciling accelerated SBTC with the productivity slowdown. Discussion Paper, vol. 118. Econometric Society.

Haltiwanger, J., Lane, J., Spletzer, J., 1999. Productivity differences across employers: the roles of employers size, age and human capital. American Economic Review 89 (2), 94-98.

Ichniowski, C., Shaw, K., 2003. Beyond incentive pay: insiders estimates of the value of complementary human resource management practices. Journal of Economic Perspectives 17 (1), 155-180.

Idson, T., Oi, W., 1999. Workers are more productive in large firms. American Economic Review 89 (2), $104-108$.

Katz, L., Autor, D., 2000. Changes in the wage structure and earnings inequality. In: Ashenfelter, O., Card, D. Handbook of Labor Economics, vol. III. Elsevier, Amsterdam. chap.

Klump, R., de La Grandville, O., 2000. Economic growth and the elasticity of substitution: two theorems and some suggestions. American Economic Review 90 (1), 282-291.

Klump, R., Preissler, H., 2000. CES production functions and economic growth. Scandinavian Journal of Economics 102 (1), $41-56$.

\footnotetext{
7 Dupuy and Marey (2004) show that the substitution parameter between skilled and unskilled labor in the US changes through time, i.e. decrease after 1978 and increase after 1990.
} 
Krusell, P., Ohanian, L., Ríos-Rull, J.-V., Violante, G., 2000. Capital-skill complementarity and inequality: a macroeconomic analysis. Econometrica 68 (5), 1029-1053.

Oi, W., 1983. Heterogeneous firms and the organization of production. Economic Inquiry 21 (2), $147-171$.

Olley, S., Pakes, A., 1996. The dynamics of productivity in the telecommunications equipment industry. Econometrica 64 (6), 1263-1297.

Papageorgiou, C., Saam, M., 2005. Two-level CES production technology in the solow and diamond growth models. Discussion Paper, vol. 2005-07. Department of Economics, Louisiana State University. 